\title{
Screening of Xylanolytic Aspergillus fumigatus for Prebiotic Xylooligosaccharide Production Using Bagasse
}

\author{
Ana Flavia Azevedo Carvalho ${ }^{1,2 *}$, Pedro de Oliva Neto², Paula Zaghetto de Almeida ${ }^{2}$, \\ Juliana Bueno da Silva ${ }^{1}$ Bruna Escaramboni ${ }^{2}$ and Glaucia Maria Pastore ${ }^{1}$ \\ ${ }^{1}$ Department of Food Science, School of Food Engineering, State University of Campinas (UNICAMP), \\ Rua Monteiro Lobato 80, 13083-862 Campinas, SP, Brazil \\ ${ }^{2}$ Department of Biological Sciences, School of Science and Letters, São Paulo State University (UNESP), \\ Rua Dom Antonio 2100, 19806-380 Assis, SP, Brazil
}

Received: March 8, 2015

Accepted: June 12, 2015

\begin{abstract}
Summary
Sugarcane bagasse is an important lignocellulosic material studied for the production of xylooligosaccharides (XOS). Some XOS are considered soluble dietary fibre, with low caloric value and prebiotic effect, but they are expensive and not easily available. In a screening of 138 fungi, only nine were shortlisted, and just Aspergillus fumigatus M51 (35.6 $\mathrm{U} / \mathrm{mL})$ and $A$. fumigatus $\mathrm{U} 2370(28.5 \mathrm{U} / \mathrm{mL})$ were selected as the most significant producers of xylanases. These fungi had low $\beta$-xylosidase activity, which is desirable for the production of XOS. The xylanases from Trichoderma reesei CCT 2768, A. fumigatus M51 and A. fumigatus U2370 gave a significantly higher XOS yield, 11.9, 14.7 and $7.9 \%$ respectively, in a 3-hour reaction with hemicellulose from sugarcane bagasse. These enzymes are relatively thermostable at $40-50^{\circ} \mathrm{C}$ and can be used in a wide range of $\mathrm{pH}$ values. Furthermore, these xylanases produced more prebiotic XOS (xylobiose and xylotriose) when compared with a commercial xylanase. The xylanases from A. fumigatus M51 reached a high level of XOS production (37.6 \%) in 48-72 h using hemicellulose extracted from sugarcane bagasse. This yield represents $68.8 \mathrm{~kg}$ of prebiotic XOS per metric tonne of cane bagasse. In addition, in a biorefinery, after hemicellulose extraction for XOS production, the residual cellulose could be used for the production of second-generation ethanol.
\end{abstract}

Key words: lignocellulosic materials, xylooligosaccharides, xylanases, bagasse

\section{Introduction}

Currently, lignocellulosic waste is a topic of global studies, given that fossil fuel reserves are diminishing, the new agricultural frontiers are limited and the demand for food and biofuels is increasing by the growing world population (1). For these reasons, technology must advance to improve the use of agricultural and agroindustrial residues to obtain food and biofuel.

Xylans present in lignocellulosic materials have been studied for obtaining xylooligosaccharides (XOS) from waste materials such as corncobs, rice hulls, olive pits, barley straw (2), tobacco stalk, cotton stalk, sunflower stalk, wheat straw (3) and sugarcane bagasse (4-6). Sugarcane bagasse is inexpensive, renewable and abundant source of XOS especially in the countries that produce ethanol and sugar from sugarcane. However, more research is necessary to improve the use of this residue.

Xylooligosaccharides are oligomers obtained from the hydrolysis of xylan extracted from lignocellulosic materials. These oligosaccharides are considered a new soluble 
dietary fibre due to their low caloric value and prebiotic effect (2). They behave as nondigestible oligosaccharides, i.e. they are not degraded in the stomach and thus reach the colon intact. XOS can beneficially affect humans by modulating the colon microbiota, especially bifidobacteria and lactobacilli (7). The addition of XOS to food has excellent physiological effects on the organism, including improvement of bowel function, calcium absorption, prevention of dental caries, protection against cardiovascular disease and reduction of colon cancer risks due to the formation of smaller chain fatty acids $(8,9)$. In addition, they contribute to beneficial effects related to skin and blood, immunological action, antioxidant activities, anti-inflammatory and antiallergenic effects $(1,10)$.

High quality XOS can be produced enzymatically using xylanases from a variety of microorganisms including: Aspergillus, Thermoascus, Trichoderma, Streptomycetes, Phanerochaetes, Chytridiomycetes, Ruminoccocus, Penicillium, Fibrobacter, Clostridium, Pichia and Bacillus (1,10-13). However, the search for more efficient xylanase-producing strains is necessary considering the production costs and low yields of production. These are the major problems of the use of enzymes for industrial applications.

Xylanases have attracted considerable attention not only for their potential application in lignocellulose hydrolysis and their bioconversion into sugars (14), but also for juice clarification, vegetable oil extraction, improvement of animal digestion, flour for baked goods, and bleaching paper pulp (15-17).

The use of residues like bagasse for growth of xylanase-producing microorganisms or substrate for enzymatic XOS production could decrease the costs of XOS (14, 18). Furthermore, the bioconversion of these substrates can help in the reduction of the environmental impact caused by the accumulation of waste (19).

The conditions for maximum production of xylanase are highly dependent on the microorganism, bioprocess and culture medium. Cellulosimicrobium cellulans produced only $0.7 \mathrm{U} / \mathrm{mL}$ of xylanase after 3 days in a culture medium containing sugarcane bagasse (18). Penicillium janczewskii cultured at $28^{\circ} \mathrm{C}$ for 7 days in a medium with nine different agroindustrial wastes confirmed the influence of the substrate on xylanase production because the best substrate $(15.4 \mathrm{U} / \mathrm{mL})$ was wheat bran, followed by oat bran $(5.8 \mathrm{U} / \mathrm{mL})$, corn cobs $(5.3 \mathrm{U} / \mathrm{mL})$, barley grain $(4.9 \mathrm{U} / \mathrm{mL})$ and cane bagasse $(3.1 \mathrm{U} / \mathrm{mL})(20)$.

In this work, a method of fungal screening using sugarcane bagasse as the sole carbon source is developed focusing on the production of xylanases and xylooligosaccharides. The enzymes of the most promising cultures were evaluated in enzymatic reaction for XOS production using xylan from bagasse.

\section{Material and Methods}

\section{Isolation and selection of xylanase-producing strains}

Samples of sugarcane bagasse were collected in Assis municipality in the western state of São Paulo, Brazil. The collected material was resuspended in peptone water 0.1 $\%$ (by mass per volume) and aseptically plated on the cul- ture medium. The optimal temperature for fungal growth on solid medium in Petri dishes was determined by incubation at 28,35 and $40{ }^{\circ} \mathrm{C}$ for $120 \mathrm{~h}$, in an incubator with a humidification system. The diameters of colonies were measured for assessment of growth after 1 to 3 days of cultivation.

The strains were isolated from sugarcane bagasse and maintained as stock cultures at $7{ }^{\circ} \mathrm{C}$ on potato dextrose agar (Acumidea, Lansing, MI, USA). Only the microorganisms that were the best producers of xylanases were identified in Chemical Biological and Agricultural Pluridisciplinary Researcher Center (CPQBA), Campinas State University, SP, Brazil.

\section{Methodology of strain identification}

The strains were identified in four steps: (i) DNA extraction according to the protocol described by Raeder and Broda (21); (ii) amplification of the region ITS1-5.8S-ITS2 and the identified calmodulin gene was done directly by DNA extraction from the samples using PCR. The primers (synthetic oligonucleotides) used in PCR reactions were ITS- 1 and ITS-4 (for the amplification of ITS region) and CF-1 and CF-4 (for the amplification of calmodulin gene); (iii) the amplified fragments (from primers ITS-1, ITS-4, CF-1 and CF-4) were purified and sequenced (automatic sequencer 3500XL series; Applied Biosystems, São Paulo, Brazil); (iv) the partial sequences of ITS and calmodulin gene obtained from different primers were assembled in a contig and compared with the sequences of GeneBank (Bethesda, MD, USA) and CBS (Utrecht, The Netherlands). The sequences were aligned using Clustal W program (22) and philogenetic analysis was performed by MEGA program (23). The matrices of evolutionary distance were calculated using the model developed by Kimura (24) and the phylogenetic tree was made by applying neighbor-joining method (25).

The strains M51 and U2370 were identified as Aspergillus fumigatus and Aspergillus fumigatus Fresenius 1863, respectively. The strain Trichoderma reesei CCT 2768 was acquired from the culture collection named Tropical Culture Collection (CCT), André Tosello Foundation, Campinas, SP, Brazil. Aspergillus fumigatus M51 was deposited in CCT with the code CCT 7732.

\section{Culture medium}

The culture medium for the isolation of xylanolytic microorganisms was prepared with (in mass \%): sugarcane bagasse 1.0, $\left(\mathrm{NH}_{4}\right)_{2} \mathrm{SO}_{4} 0.2, \mathrm{MgSO}_{4} \cdot 7 \mathrm{H}_{2} \mathrm{O} 0.01, \mathrm{~K}_{2} \mathrm{H}$ $\mathrm{PO}_{4} 0.1, \mathrm{KH}_{2} \mathrm{PO}_{4} 0.1$, yeast extract 0.01 , micronutrient solution $0.1\left(\mathrm{FeSO}_{4} \cdot 7 \mathrm{H}_{2} \mathrm{O} 0.1, \mathrm{MnSO}_{4} \cdot \mathrm{H}_{2} \mathrm{O} 0.005\right.$ and $\mathrm{ZnSO}_{4}$ 0.02 ), and in \% (by mass per volume) agar-agar 2 and chloramphenicol 0.018 and sterilised at $121{ }^{\circ} \mathrm{C}$ for $20 \mathrm{~min}$.

\section{Cultivation and enzyme production}

Xylanases were produced by submerged fermentation $(\mathrm{SmF})$ in Erlenmeyer flasks $(250 \mathrm{~mL})$ containing $50 \mathrm{~mL}$ of medium composed of sugarcane bagasse $3.0 \%$ (by mass per volume) and (in mass \%): $\left(\mathrm{NH}_{4}\right)_{2} \mathrm{SO}_{4} 0.2, \mathrm{MgSO}_{4} \cdot 7 \mathrm{H}_{2} \mathrm{O}$ $0.01, \mathrm{~K}_{2} \mathrm{HPO}_{4} 0.1, \mathrm{KH}_{2} \mathrm{PO}_{4} 0.1$, yeast extract 0.5 and micronutrient solution $0.1\left(\mathrm{FeSO}_{4} \cdot 7 \mathrm{H}_{2} \mathrm{O} 0.1, \mathrm{MnSO}_{4} \cdot \mathrm{H}_{2} \mathrm{O} 0.005\right.$ 
and $\mathrm{ZnSO}_{4}$ 0.02) at $\mathrm{pH}=5.0$. The culture medium was inoculated with $10^{6}$ spores per $\mathrm{mL}$ counted by microscopy in a Neubauer chamber. The flasks were incubated at the optimal growth temperature with orbital shaking (model TE421; Tecnal, São Paulo, Brazil) at $180 \mathrm{rpm}$ for $144 \mathrm{~h}$. The biomass was separated by filtering through gauze and filter paper. The filtrate was used as a crude xylanase complex. Fermentations were carried out in triplicate.

\section{Enzymatic activities}

Two tests were performed to determine xylanase and $\beta$-xylosidase activities. Enzyme activity was assayed at 50 ${ }^{\circ} \mathrm{C}$ in a reaction mixture containing $0.1 \mathrm{~mL}$ of diluted crude enzyme and $0.65 \mathrm{~mL}$ of substrate solution in $0.25 \mathrm{M}$ sodium acetate buffer, $\mathrm{pH}=5.0$. The used substrate was $0.5 \%$ (by mass per volume) birchwood xylan (Sigma-Aldrich, Darmstadt, Germany). The amount of reducing sugars was quantified by the dinitrosalicylic acid method (26). One unit (U) of xylanase activity was defined as the amount of enzyme that releases carbohydrates having a reducing power corresponding to $1 \mu \mathrm{mol}$ of $\mathrm{D}$-xylose from birch xylan per minute under assay conditions. When 4-nitrophenyl- $\beta$-D-xylopyranoside (PNPX) was used as a substrate, the $\beta$-xylosidase activity was measured in a mixture containing $0.25 \mathrm{~mL}$ of $100 \mathrm{mM}$ sodium acetate, $\mathrm{pH}=$ $5.0,0.25 \mathrm{~mL}$ of $4 \mathrm{mM}$ substrate solution, and $0.05 \mathrm{~mL}$ of crude enzyme. After $10 \mathrm{~min}$ of incubation at $50{ }^{\circ} \mathrm{C}$ the reaction was stopped by adding $2 \mathrm{~mL}$ of $2 \mathrm{M}$ sodium carbonate, and the released $p$-nitrophenol was quantified spectrophotometrically at $410 \mathrm{~nm}$. One unit (U) of $\beta$-xylosidase activity was defined as the amount of enzyme that releases $1 \mu \mathrm{mol}$ of $p$-nitrophenol per minute in the reaction mixture (27).

\section{Enzyme characterisation}

Optimum $\mathrm{pH}$ and temperature for enzyme activity

A $2^{2}$ full factorial design with four replicates at the midpoint was used to evaluate the influence of two different variables, temperature and $\mathrm{pH}$. They were studied to determine their effect on xylanolytic activity of fungal crude enzymes. The xylanase activities $(\mathrm{U} / \mathrm{mL})$ were taken as dependent variables or response of the experimental design. To fit an empirical second-order polynomial model, a central composite design was used. The results were analysed by the response surface analysis using STATISTICA v. 6.0 software (StatSoft Inc., Tulsa, OK, USA).

\section{Thermostability}

The crude enzyme solution was incubated at various temperatures $\left(40-95^{\circ} \mathrm{C}\right)$ for 1 and $3 \mathrm{~h}$ at $\mathrm{pH}=7.0$ in sealed tubes to prevent evaporation. Water was used instead of crude enzyme as a control. In both assays, an aliquot was removed and placed on ice before assaying for residual enzyme activity at the optimal $\mathrm{pH}$ and temperature.

\section{pH stability}

Crude enzyme was dissolved in $0.1 \mathrm{M}$ buffer solution (1:1) at $\mathrm{pH}=3.0-5.5$ (acetate), $\mathrm{pH}=5.5-8.0$ (Mcllvaine) and $\mathrm{pH}=8.0-10.0$ (glycine- $\mathrm{NaOH}$ ) and maintained at $25^{\circ} \mathrm{C}$ for $24 \mathrm{~h}$. Afterwards, residual xylanolytic activity was determined under optimal conditions of $\mathrm{pH}=5.5$ at $55^{\circ} \mathrm{C}$.

\section{Extraction and chemical characterisation of hemicellulose}

The method used for the extraction of hemicellulose was described by Zilliox and Debeire (28) and Akpinar et al. (29), with slight modifications. A sample of $20 \mathrm{~g}$ of sugarcane bagasse was swollen in water at $60{ }^{\circ} \mathrm{C}$ for $16 \mathrm{~h}$. Then it was treated for $3 \mathrm{~h}$ at $35^{\circ} \mathrm{C}$ with $24 \% \mathrm{KOH}$ including $1 \%$ (by mass per volume) $\mathrm{NaBH}_{4}$. The extract was filtered through a gauze, and the xylan present in the supernatant was precipitated in 2 volumes of cold ethanol and 0.2 volume of acetic acid, then washed tree times with 70 $\%$ ethanol and centrifuged at $5300 \times g$ for $20 \mathrm{~min}$. After centrifugation, the solid was dried using an air circulation oven at $45{ }^{\circ} \mathrm{C}$. The yield of crude hemicellulose (precipitated material extracted from bagasse) was $25.4 \%$, but only $71.9 \%$ of this material was pure hemicellulose. Therefore, the yield of the pure hemicellulose extracted from bagasse was $18.3 \%$.

\section{Chemical composition of bagasse and hemicellulose}

The chemical composition of bagasse used in this work was determined according to the method described by Sluiter et al. (30), and it contained (in mass \%): cellulose 40.3 (glucan 40.3), hemicellulose 25.1 (arabinan 1.9, galactan 0.5, xylan 21.9 and mannan 0.8), total lignin 25.2 (soluble lignin 1.7 and insoluble lignin 23.5) and ash 4.5. The crude extracted hemicellulose ( $25.4 \%$ from bagasse) was composed of (in mass \%): glucan 3.4, hemicellulose 71.9 (arabinan 5.7, galactan 0.6, xylan 63.6 and mannan 2.0), total lignin 9.4 (soluble lignin 1.5 and insoluble lignin 7.9) and ash 12.7 .

\section{Production of XOS by enzymatic reaction of xylanases}

The enzymatic reaction was performed using the mixture of 60-500 U of xylanases (NS 22083; Novozymes, Bagsværd, Denmark) or crude enzymes from selected fungi per $\mathrm{g}$ of substrate in a total volume of $10 \mathrm{~mL}$ of 100 $\mathrm{mM}$ acetate buffer $(\mathrm{pH}=5.0)$ in a $20-\mathrm{mL}$ glass test tube. The hemicellulose 1-2 \% (by mass per volume) extracted from bagasse (as previously described) was used as substrate. According to Novozyme, the commercial xylanase (NS22083) was a purified endoxylanase with optimal conditions of $35-55{ }^{\circ} \mathrm{C}$ and $\mathrm{pH}=4.5-6.0$. The mixture was incubated at $(50 \pm 1)^{\circ} \mathrm{C}$ for $1-96 \mathrm{~h}$ in a shaker (model TE 405; Tecnal) at $130 \mathrm{rpm}$. The hydrolysis was stopped by boiling in a water bath for $10 \mathrm{~min}$. The xylooligosaccharides released during the reaction were analysed by HPLC (ICS-5000; Dionex, Sunnyvale, CA, USA). The experiment was performed in triplicate. Statistical analysis was performed to compare XOS production by the xylanases of different fungi and with the commercial xylanase using the ANOVA and Tukey's tests in the STATISTICA v. 6.0 software.

\section{Determination and yield of xylooligosaccharides}

The carbohydrates formed during enzymatic hydrolysis were quantified using an anion exchange column, CarboPac PA100 on a HPLC (ICS-5000; Dionex). The elution was done with $0.2 \mathrm{M}$ sodium hydroxide and $0.5 \mathrm{M}$ sodium acetate with linear gradient (0-20\%) for $10 \mathrm{~min}$, followed by a wash step with $0.5 \mathrm{M}$ sodium acetate for 5 min. Finally, the solution was stabilized with $0.2 \mathrm{M}$ sodium hydroxide for $7 \mathrm{~min}$ at a flow rate of $1 \mathrm{~mL} / \mathrm{min}$. The 
standards (Sigma-Aldrich) used were xylose $(3.4 \mathrm{~min})$, xylobiose $(4.8 \mathrm{~min})$, xylotriose $(7.6 \mathrm{~min})$, xylotetraose $(9.1$ $\mathrm{min})$, xylopentaose $(9.9 \mathrm{~min}$ ) and xylohexaose $(10.6 \mathrm{~min})$. The XOS yield was determined by the following equation:

$$
Y(\mathrm{XOS})=\left(\frac{m \text { (total XOS })}{m \text { (hemicellulose })}\right) \cdot 100
$$

where total XOS is the sum of xylobiose, xylotriose, xylotetraose, xylopentaose and xylohexaose masses (in g).

\section{Results}

\section{Isolation and selection of xylanolytic fungi}

Xylanolytic fungi were selected from 138 strains isolated from agar sugarcane culture medium by plating from samples. Only nine strains (Table 1) showed colonies with diameters of $0.8 \mathrm{~cm}$ or larger, and they were selected for the production of xylanase by submerged fermentation $(\mathrm{SmF})$, showing activity from 8.9 to $43.7 \mathrm{U} / \mathrm{mL}$.

Table 1. Properties of xylanolytic fungi selected by plating and submerged fermentation in a medium with sugarcane bagasse culture medium

\begin{tabular}{|c|c|c|c|c|}
\hline Strain & $t$ & $d($ colony $)$ & $\begin{array}{c}\text { Xylanase } \\
\text { activity } \\
\end{array}$ & $\begin{array}{c}\beta \text {-xylosidase } \\
\text { activity }\end{array}$ \\
\hline & ${ }^{\circ} \mathrm{C}$ & $\mathrm{cm}$ & $\mathrm{U} / \mathrm{mL}$ & $\mathrm{U} / \mathrm{mL}$ \\
\hline FS08 & 28 & 3.5 & $20.3 \pm 5.6$ & $0.03 \pm 0.003$ \\
\hline MT06B & 28 & 3.5 & $8.9 \pm 0.8$ & $0.01 \pm 0.01$ \\
\hline M51 & 35 & 0.8 & $35.6 \pm 7.2$ & $0.03 \pm 0.01$ \\
\hline $100 \mathrm{P}$ & 35 & 2.5 & $14.6 \pm 4.4$ & $0.02 \pm 0.02$ \\
\hline $\begin{array}{l}\text { T. reesei } \\
\text { CCT } 2768\end{array}$ & 35 & 4.5 & $43.7 \pm 6.6$ & $0.04 \pm 0.02$ \\
\hline $\mathrm{U} 2370$ & 35 & 1.5 & $28.5 \pm 1.3$ & $0.04 \pm 0.02$ \\
\hline B10 & 35 & 3.5 & $14.4 \pm 2.8$ & $0.02 \pm 0.03$ \\
\hline U19 & 35 & 3.5 & $18.4 \pm 6.4$ & $0.00 \pm 0.00$ \\
\hline U20 & 35 & 0.8 & $16.8 \pm 2.1$ & $0.05 \pm 0.02$ \\
\hline
\end{tabular}

\section{Production of xylanases in submerged fermentation}

The best producers of xylanases were identified as Trichoderma reesei CCT 2768 (43.7 U/mL), Aspergillus fumigatus M51 (35.6 U/mL) and A. fumigatus U2370 (28.5 U/ $\mathrm{mL}$ ) using sugarcane bagasse as the sole carbon source for 5 days of incubation (Table 1). The production of $\beta$ -xylosidase by these fungi was very low when compared with the xylanase activity. The maximum $\beta$-xylosidase activity was $0.05 \mathrm{U} / \mathrm{mL}$ (Table 1 ).

\section{Effects of temperature and $p H$ of the reaction on the xylanase activity}

The enzymatic reaction of selected fungi was carried out at $50{ }^{\circ} \mathrm{C}$ and $\mathrm{pH}=5.0$; however, the optimisation of these parameters was determined to obtain higher xylanolytic activity for each crude enzyme.

The values obtained from $2^{2}$ full factorial design, with coded and uncoded values, and results for xylanase activity of T. reesei CCT 2768, A. fumigatus M51 and A. fumigatus U2370 are shown in Table 2.

The optimal $\mathrm{pH}$ and temperature values were calculated by deriving equations from the second order uncoded model, which describes the relationship of these dependent variables and the enzyme activity (independent variable). The following equations refer to the xylanase activity in the extracts of $T$. reesei CCT 2768, A. fumigatus $\mathrm{U} 2370$ and $A$. fumigatus M51, respectively:

$$
\begin{aligned}
& \text { Xylanase activity }=46.7-1.7 \cdot t-19.0 \cdot \mathrm{pH}^{2}-17.9 \cdot t^{2} \quad \mathrm{R}^{2}=9.0 \% \quad / 2 / \\
& \text { Xylanase activity }=26.5-10.9 \cdot \mathrm{pH}^{2}-10.7 \cdot t^{2} \quad \mathrm{R}^{2}=98.1 \% / 3 / \\
& \text { Xylanase activity }=33.1-13.5 \cdot \mathrm{pH}^{2}-12.8 \cdot t^{2} \quad \mathrm{R}^{2}=96.2 \% \quad / 4 /
\end{aligned}
$$

The crude enzymes from $T$. reesei CCT 2768 and $A$. fumigatus M51 showed the highest xylanase activity at 55 ${ }^{\circ} \mathrm{C}$ and $\mathrm{pH}=5.5$, and of $A$. fumigatus U2370 at $55{ }^{\circ} \mathrm{C}$ and $\mathrm{pH}=6.0$. The ranges of $\mathrm{pH}$ and temperature of enzymatic reaction to maintain at least $90 \%$ of original xylanolytic

\begin{tabular}{|c|c|c|c|c|c|c|c|}
\hline \multirow[t]{2}{*}{ Run } & \multicolumn{2}{|c|}{ Coded values } & \multicolumn{2}{|c|}{ Uncoded values } & \multicolumn{3}{|c|}{ Xylanase activity/(U/mL) } \\
\hline & $\mathrm{pH}$ & $t /{ }^{\circ} \mathrm{C}$ & $\mathrm{pH}$ & $t /{ }^{\circ} \mathrm{C}$ & T. reesei CCT 2768 & A. fumigatus U2370 & A. fumigatus M51 \\
\hline 1 & -1 & -1 & 3.7 & 34 & 12.1 & 2.9 & 3.0 \\
\hline 2 & 1 & -1 & 7.3 & 34 & 11.8 & 6.3 & 8.7 \\
\hline 3 & -1 & 1 & 3.7 & 76 & 7.2 & 2.5 & 3.0 \\
\hline 4 & 1 & 1 & 7.3 & 76 & 7.1 & 3.8 & 5.9 \\
\hline 5 & -1.41 & 0 & 3.0 & 55 & 8.5 & 4.1 & 6.4 \\
\hline 6 & 1.41 & 0 & 8.0 & 55 & 9.2 & 6.9 & 9.5 \\
\hline 7 & 0 & -1.41 & 5.5 & 25 & 12.7 & 5.0 & 6.4 \\
\hline 8 & 0 & 1.41 & 5.5 & 85 & 9.6 & 6.9 & 12.2 \\
\hline 9 & 0 & 0 & 5.5 & 55 & 46.7 & 26.4 & 33.3 \\
\hline 10 & 0 & 0 & 5.5 & 55 & 46.4 & 27.3 & 32.2 \\
\hline 11 & 0 & 0 & 5.5 & 55 & 47.1 & 25.8 & 33.9 \\
\hline 12 & 0 & 0 & 5.5 & 55 & 46.6 & 26.3 & 32.2 \\
\hline
\end{tabular}
activity were $\mathrm{pH}=5.0$ to 6.5 and 45 to $65^{\circ} \mathrm{C}$ in T. reesei CCT

Table 2. Factorial design used for evaluating the activity of xylanolytic strains Trichoderma reesei CCT 2768, Aspergillus fumigatus M51 and A. fumigatus U2370 
2768, A. fumigatus $\mathrm{U} 2370$ and A. fumigatus M51. On the other hand, at $\mathrm{pH}$ below 3.5 the enzyme activity decreased considerably, obtaining less than $50 \%$ of the maximum enzyme activity (Fig. 1). This result indicates that extremely acidic conditions are not recommended for these enzymes. Under slightly alkaline conditions $(\mathrm{pH}=7.5)$, the xylanase activity in the crude enzyme from $A$. fumigatus U2370 retained $71 \%$ of the maximum activity (Fig. 1b), but less than $55 \%$ of the xylanolytic activity of the crude enzymes from T. reesei CCT 2768 and A. fumigatus M51 was obtained (Figs. 1a and c).

The thermostability of the crude enzymes from T. reesei CCT2768, A. fumigatus M51 and A. fumigatus U2370
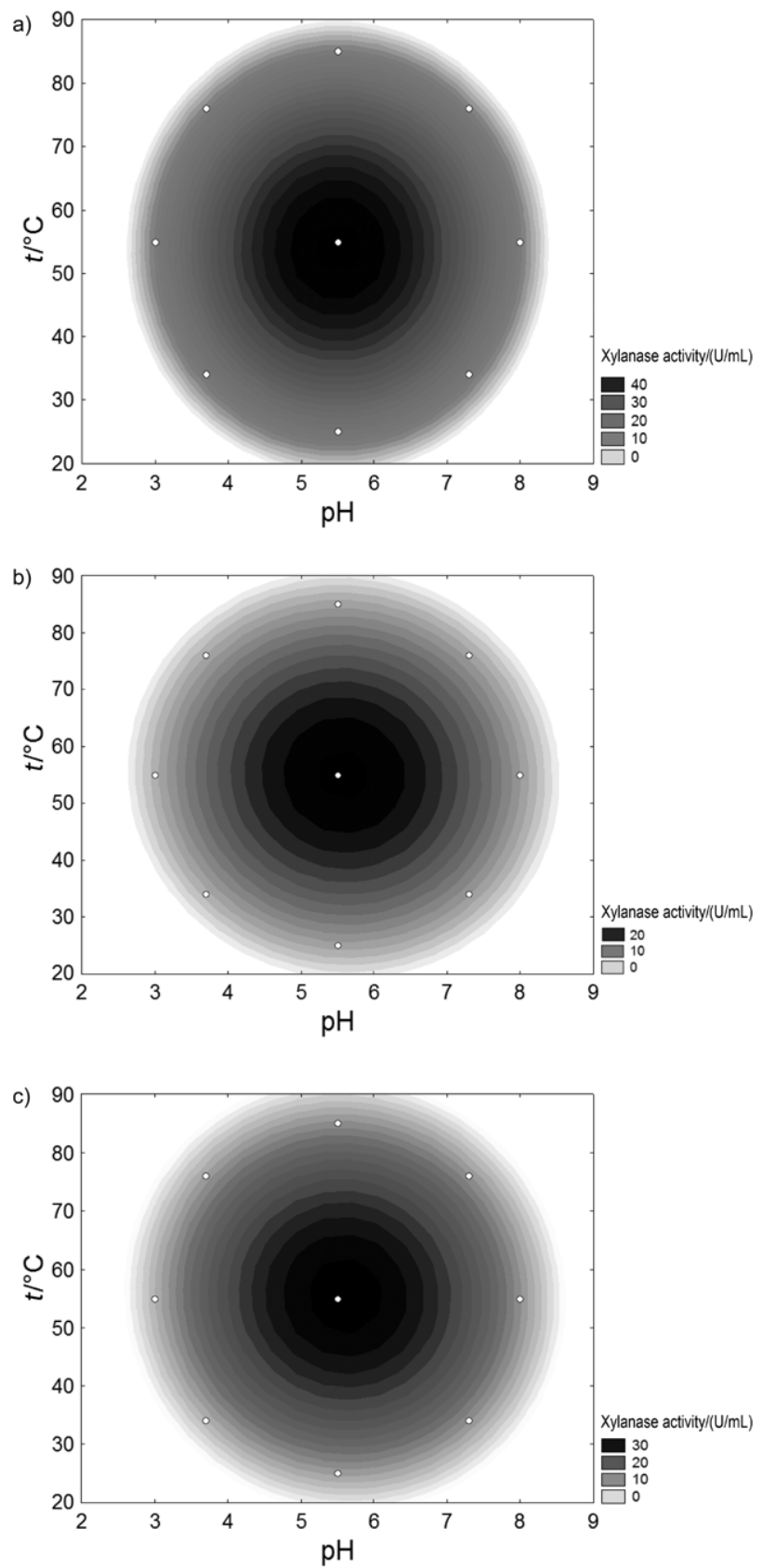

Fig. 1. Effect of reaction temperature and $\mathrm{pH}$ on the activity of xylanase from: a) Trichoderma reesei CCT 2768, b) Aspergillus fumigatus $\mathrm{U} 2370$ and c) A. fumigatus M51 was similar, and $100 \%$ of the xylanase activity at $10{ }^{\circ} \mathrm{C}$ was maintained for 1 to $3 \mathrm{~h}$ at 25 to $40^{\circ} \mathrm{C}$. At $50^{\circ} \mathrm{C}$ for $1 \mathrm{~h}$, 64,60 and $61 \%$ of the xylanolytic activity of the enzymes from these three fungi at $10{ }^{\circ} \mathrm{C}$ were maintained, respectively. When they were incubated at $60{ }^{\circ} \mathrm{C}$ for $1 \mathrm{~h}$, only 3 , 7 and $11 \%$ of their activities at $10{ }^{\circ} \mathrm{C}$ remained, respectively. Finally, at higher temperatures $\left(70-95{ }^{\circ} \mathrm{C}\right)$ the enzymes from the three fungi had completely lost their xylanolytic activity in $1 \mathrm{~h}$ of incubation (Fig. 2a). However, after $3 \mathrm{~h}$ at $50{ }^{\circ} \mathrm{C}$, only the crude enzymes from $T$. reesei CCT 2768 showed a higher decrease $(28 \%)$ of the original activity at $10{ }^{\circ} \mathrm{C}$. The enzymes from $A$. fumigatus M51 and A. fumigatus U2370 maintained 54 and $56 \%$ of their original activity, respectively. In addition, at $40{ }^{\circ} \mathrm{C}$ the three enzymes remained $100 \%$ stable during $3 \mathrm{~h}$ of incubation (Fig. 2b). These results demonstrated a higher thermostability of the xylanases of A. fumigatus than the enzyme of T. reesei CCT 2768.

The $\mathrm{pH}$ stability of enzymes from $T$. reesei CCT 2768 , A. fumigatus U2370 and A. fumigatus M51 showed more than $87 \%$ stability under acidic conditions in the $\mathrm{pH}$ range from 4 to 6 . Even in the range of $\mathrm{pH}=7$ to 9 , between 70 and $100 \%$ of the original activity remained stable. However, at $\mathrm{pH}=10$ the stability was greatly reduced (more than $82 \%$ ) (Fig. 2c).
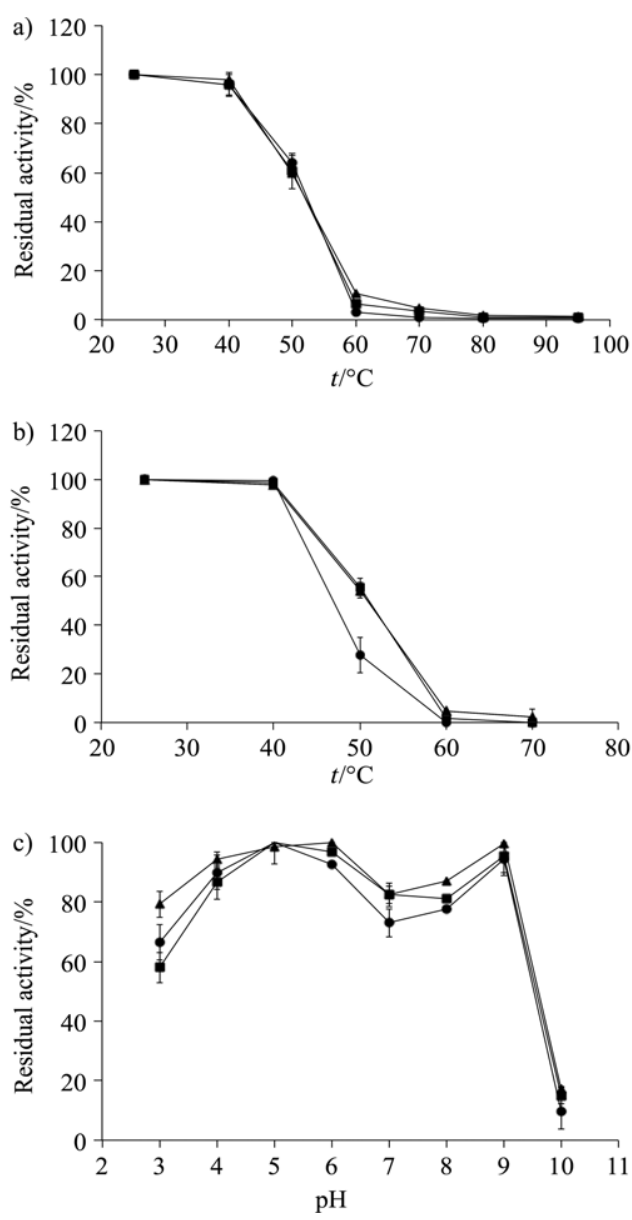

Fig. 2. Thermostability of the crude enzymes of preselected fungi incubated for: a) $1 \mathrm{~h}$ and b) $3 \mathrm{~h}$, and c) $\mathrm{pH}$ stability. Symbols: (•) Trichoderma reesei CCT 2768, (•) Aspergillus fumigatus U2370, and (ム) A. fumigatus M51 


\section{Production of XOS by enzymatic hydrolysis}

The enzymes from the three selected fungi were compared to the commercial endoxylanase (NS 22083) for XOS production by the enzymatic hydrolysis of hemicellulose extracted from sugarcane bagasse. The total XOS production of the xylanase from $A$. fumigatus M51 (1.04 $\mathrm{mg} / \mathrm{mL})$ and T. reesei CCT $2768(0.88 \mathrm{mg} / \mathrm{mL})$ was significantly higher $(\mathrm{p}<0.05)$ than the xylanase from $A$. fumigatus U2370 $(0.54 \mathrm{mg} / \mathrm{mL})$. The commercial xylanase also had lower activity $(0.50 \mathrm{mg} / \mathrm{mL})$.

Another important aspect was the type of xylooligosaccharide produced. The reactions with the enzyme from A. fumigatus M51 showed a significantly higher concentrations $(\mathrm{p}<0.05)$ of xylobiose $(0.59 \mathrm{mg} / \mathrm{mL})$ and xylotriose $(0.45 \mathrm{mg} / \mathrm{mL})$ than of xylotetraose, xylopentaose and xylohexaose (less than $0.01 \mathrm{mg} / \mathrm{mL}$ each).

On the other hand, the commercial xylanase Novozymes NS 22083 produced significantly lower amount $(\mathrm{p}<0.05)$ of xylobiose $(0.51 \mathrm{mg} / \mathrm{mL})$ and xylotriose $(0.08$ $\mathrm{mg} / \mathrm{mL}$ ) than the xylanases from A. fumigatus M51. The smallest fraction of the sugars obtained from the hemicellulose was again of xylose; only $0.04 \mathrm{mg} / \mathrm{mL}$ was produced by A. fumigatus M51 and $0.10 \mathrm{mg} / \mathrm{mL}$ by T. reesei CCT 2768 (Table 3).

The highest and significant $(\mathrm{p}<0.05)$ yield of XOS was obtained from the crude enzyme from A. fumigatus M51 (14.7\%), followed by T. reesei CCT 2768 (11.9\%) in just $3 \mathrm{~h}$ of reaction time. The commercial enzyme had much lower XOS yield when compared to the enzymes from $A$. fumigatus M51. According to these results, the enzymes from A. fumigatus M51 showed great potential for use in the production of short-chain XOS, since this crude enzyme was superior to the purified Novozymes xylanase (NS 22083) and other fungal enzymes evaluated under the same conditions and enzyme amount. The improvement in XOS yield was obtained in another assay (Fig. 3) performed using different reaction times and dosages of enzymes from A. fumigatus M51. There was no significant difference $(\mathrm{p}<0.05)$ in XOS production with 120 and $500 \mathrm{U} / \mathrm{g}$ hemicellulose, and the maximum level of XOS yield was obtained (35-37.6 \%) in 48-72 h with $2 \%$ hemicelullose.

\section{Discussion}

Microorganisms selected in this work exhibited weak $\beta$-xylosidase activity, which is favourable for XOS pro-

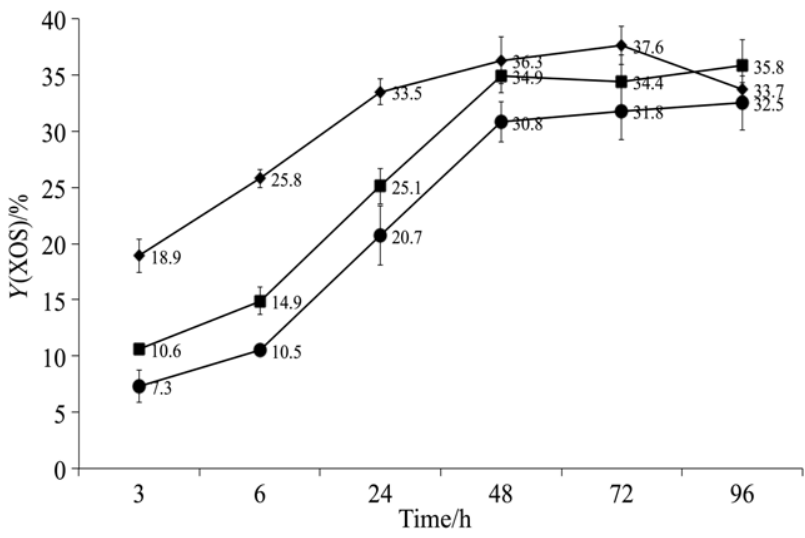

Fig. 3. The loading effect of xylanase $(\bullet 60,-120$ and $\bullet 500 \mathrm{U} /$ $\mathrm{mL}$ ) from Aspergillus fumigatus M51 on the production of xylooligosaccharides (XOS) by hemicellulose hydrolysis at $50{ }^{\circ} \mathrm{C}$

duction, since lower xylose production means weaker hydrolysis of XOS released by xylanases. According to Vázquez et al. (31) xylanases are inhibited by xylose at higher concentrations.

The xylanase activity was higher in Aspergillus fumigatus M51 (35.6 U/mL) than in A. awamori 2B.361 U2/1 (25.0 U/mL), Trichoderma reesei RUT-C30 (10.0 U/mL), Cellulosimicrobium cellulans $(0.7 \mathrm{U} / \mathrm{mL})$, Penicillium janczewskii (3.1 U/mL) and P. echinulatum $(1.49 \mathrm{U} / \mathrm{mL})$ using the same substrate (bagasse) in submerged fermentation $(12,18$ 20 ). The xylanase activity of $P$. janthinellum using pretreated bagasse and corncob was 23.0 and $23.8 \mathrm{U} / \mathrm{mL}$, respectively (32).

The crude xylanases from A. fumigatus M51 were stable in a wide range of $\mathrm{pH}=4-9$, in which they maintained between 70 and $100 \%$ of the original activity. Therefore, these enzymes can be used in industry under different conditions including acidic, neutral and alkaline environment. A lower range of optimal $\mathrm{pH}$ values (4.0-6.0) for xylanase activity was found in other fungi, e.g. Schizophyllum commune ATCC 38548, A. awamori and Aspergillus sp. $(33,34)$. Xylanases from $A$. caespitosus remained stable in the $\mathrm{pH}$ range of 5-7 (35). On the other hand, the best xylanase activity produced by $A$. foetidus MTCC 4898 was at $\mathrm{pH}=5.3$, but decreased by 34 and $50 \%$ at $\mathrm{pH}=4.5$ and 6.0 , respectively (36).

Table 3. Production of xylooligosacharides (XOS) by enzymatic hydrolysis of selected fungal enzymes using hemicellulose extracted from sugarcane bagasse

\begin{tabular}{|c|c|c|c|c|c|c|}
\hline \multirow{2}{*}{ Microorganism } & \multirow{2}{*}{$\frac{\text { Reaction time }}{\mathrm{h}}$} & \multicolumn{4}{|c|}{$\gamma /(\mathrm{mg} / \mathrm{mL})$} & \multirow{2}{*}{$\frac{Y(\mathrm{XOS})}{\%}$} \\
\hline & & Xylose & Xylobiose & Xylotriose & Total XOS & \\
\hline \multirow{2}{*}{ T. reesei ССТ 2768} & 1 & 0.04 & 0.23 & 0.17 & $0.40 \pm 0.005$ & 5.4 \\
\hline & 3 & 0.10 & 0.51 & 0.38 & $0.88 \pm 0.008$ & 11.9 \\
\hline \multirow{2}{*}{ A. fumigatus M51 } & 1 & 0.02 & 0.28 & 0.21 & $0.50 \pm 0.013$ & 7.1 \\
\hline & 3 & 0.04 & 0.59 & 0.45 & $1.04 \pm 0.013$ & 14.7 \\
\hline \multirow{2}{*}{ A. fumigatus 2370} & 1 & 0.02 & 0.13 & 0.10 & $0.23 \pm 0.03$ & 3.4 \\
\hline & 3 & 0.05 & 0.31 & 0.24 & $0.54 \pm 0.02$ & 7.9 \\
\hline \multirow{2}{*}{ Novozyme NS 22083} & 1 & 0.03 & 0.23 & 0.10 & $0.32 \pm 0.001$ & 3.9 \\
\hline & 3 & 0.02 & 0.51 & 0.08 & $0.59 \pm 0.009$ & 7.1 \\
\hline
\end{tabular}

Reaction time was measured at $50{ }^{\circ} \mathrm{C}, \mathrm{pH}=5.0$ and $500 \mathrm{U}$ of xylanases per $\mathrm{g}$ of substrate. Total $\mathrm{XOS}=$ sum of xylobiose and xylotriose 
The xylanases from A. fumigatus M51 and A. fumigatus $\mathrm{U} 2370$ showed higher thermostability at 10 to $50^{\circ} \mathrm{C}$ for 1 to $3 \mathrm{~h}$ of incubation than the xylanase from T. reesei CCT 2768 (10 to $\left.40{ }^{\circ} \mathrm{C}\right)$. The same result was obtained for Aspergillus sp. FP-470 (33). However, an inferior thermostability (10$40{ }^{\circ} \mathrm{C}$ ) was found for xylanases of Schizophyllum commune ATCC 38548 (34).

The XOS yield obtained by enzymatic reaction can be influenced by several factors including the type and concentration of xylanase, source and concentration of hemicellulose, xylan composition, type of pretreatment and reaction time, among others $(1,3)$. In the present work, the effects of enzyme concentration and reaction time were important to increase XOS yield up to $31-36 \%$ in $48 \mathrm{~h}$ with $60-500 \mathrm{U}$ of xylanase per $\mathrm{g}$ of substrate (Fig. 3). A similar XOS yield (37.1\%) was obtained by crude enzyme from Thermoascus aurantiacus with $2 \%$ hemicellulose from cane bagasse, $60 \mathrm{U}$ per $\mathrm{g}$ of substrate, but with longer reaction time $(96 \mathrm{~h})$ at $50{ }^{\circ} \mathrm{C}$ and $\mathrm{pH}=5.0$ (11). Another similar XOS yield $(36.8 \%)$ was obtained with the reaction of hemicellulose from Populus tomentosa and $25 \mathrm{U}$ of crude xylanase from Pichia stipites per $\mathrm{g}$ of substrate at $50{ }^{\circ} \mathrm{C}$ and $\mathrm{pH}=5.4$, but in only $14 \mathrm{~h}$ (13). However, a low yield of XOS $(8.6 \%)$ was obtained when only $13.3 \mathrm{U}$ of endoxylanase from Trichoderma viridae (Sigma-Aldrich) per $\mathrm{g}$ of substrate were added (37). In addition, a XOS yield of only $11.4 \%$ was obtained with hemicellulose extracted from tobacco stalk, after $24 \mathrm{~h}$ of hydrolysis using $20 \mathrm{U}$ of xylanase from $A$. niger per $g$ of substrate at $40^{\circ} \mathrm{C}(3)$.

From the yield of hemicellulose extracted from bagasse $(18.3 \%)$, and yield of XOS from hemicellulose (37.6 \%; Fig. 3), is possible to obtain $68.8 \mathrm{~kg}$ of prebiotic XOS per metric tonne of sugarcane bagasse by the above mentioned enzymatic reaction. In addition, in a biorefinery model, after extraction of hemicellulose used for XOS production, the residual cellulose can be used for the production of second-generation ethanol in the same industrial plant.

The enzymatic method resulted in the production of XOS with degree of polymerisation (DP) of 2-3, while chemical hydrolysis (autohydrolysis or acid hydrolysis) produced these, but also other XOS with higher DP $(2,38-$ 40), without prebiotic effect. Commercial XOS (Xylooligo 95P; Suntory, Osaka, Japan), produced by autohydrolysis, containing $83 \%$ of xylobiose and xylotriose were used in the culture medium as carbon source. These XOS were responsible for higher growth of Bifidobacterium strains ( $B$. adolescentis and B. longum) than the culture with the medium formulated with XOS with higher DP and containing only $24-41 \%$ of xylobiose and xylotriose. Furthermore, XOS with $\mathrm{DP}=5-6$ reduced the degree of consumption of these oligosaccharides by the bacteria (41). Therefore, the quality of the produced XOS is important when considering the prebiotic effect. In the present work, xylobiose and xylotriose were predominant XOS in the culture madium, which made it more suitable for selective Bifidobacterium growth.

\section{Conclusion}

The strain Aspergillus fumigatus M51 was selected by a screening method developed to obtain fungal xylanases with the ability to produce xylooligosaccharides (XOS) from sugarcane bagasse. A significant level of xylanase was obtained by submerged fermentation. This crude enzyme is thermostable at $40-50{ }^{\circ} \mathrm{C}$ and can be used in a wide range of $\mathrm{pH}$. The $A$. fumigatus M51 xylanase produced more prebiotic XOS (xylobiose and xylotriose) than a commercial xylanase. The research also showed the potential of using sugarcane bagasse as feedstock for the production of xylanases and prebiotic xylooligosaccharides.

\section{Acknowledgements}

The authors wish to thank the São Paulo Researcher Foundation (FAPESP) and the National Brazilian Research Foundation $(\mathrm{CNPq})$ for financial support and the André Tosello Foundation for donation of the fungal strain.

\section{References}

1. Carvalho AFA, Oliva-Neto P, Silva DF, Pastore GM. Xylooligosaccharides from lignocellulosic materials: Chemical structure, health benefits and production by chemical and enzymatic hydrolysis. Food Res Int. 2013;51:75-85.

http://dx.doi.org/10.1016/j.foodres.2012.11.021

2. Nabarlatz D, Ebringerová A, Montané D. Autohydrolysis of agricultural by-products for the production of xylooligosaccharides. Carbohydr Polym. 2007;69:20-8. http://dx.doi.org/ 10.1016/j.carbpol.2006.08.020

3. Akpinar O, Erdogan K, Bostanci S. Enzymatic production of xylooligosaccharide from selected agricultural wastes. Food Bioprod Process. 2009; 87:145-51.

http://dx.doi.org/10.1016/j.fbp.2008.09.002

4. Brienzo M, Siqueira AF, Milagres AMF. Search for optimum conditions of sugarcane bagasse hemicellulose extraction. Biochem Eng J. 2009;46:199-204. http://dx.doi.org/ 10.1016/j.bej.2009.05.012

5. Rodrigues RCLB, Rocha GJM, Rodrigues D, Izário Filho HJ, Felipe MGA, Pessoa A. Scale-up of diluted sulfuric acid hydrolysis for producing sugarcane bagasse hemicellulosic hydrolysate (SBHH). Bioresour Technol. 2010;101:1247-53. http://dx.doi.org/10.1016/j.biortech.2009.09.034

6. Santos DT, Sarrouh BF, Rivaldi JD, Converti A, Silva SS. Use of sugarcane bagasse as biomaterial for cell immobilization. J Food Eng. 2008;86:542-8. http://dx.doi.org/10.1016/j.jfoodeng.2007.11.004

7. Gullón P, Moura P, Esteves M, Girio FM, Domínguez H, Parajó JC. Assessment on the fermentability of xylooligosaccharides from rice husks by probiotic bacteria. J Agric Food Chem. 2008;56:7482-7. http://dx.doi.org/10.1021/jf800715b

8. Grootaert C, Delcour JA, Courtin CM, Broekaert WF, Verstraete W, Wiele TV. Microbial metabolism and prebiotic potency of arabinoxylan oligosaccharides in the human intestine. Trends Food Sci Tech. 2007;18:64-71. http://dx.doi.org/10.1016/j.tifs.2006.08.004

9. Wang J, Yuan X, Sun B, Cao Y, Tian Y, Wang C. On-line separation and structural characterization of feruloylated oligosaccharide from wheat bran using HPLC-ESI-MSn . Food Chem. 2009;115:1529-41. http://dx.doi.org/10.1016/j.foodchem.2009.01.058

10. Aachary AA, Prapulla SG. Value addition to corncob: Production and characterization of xylooligosaccharides from alkali pretreated lignin-saccharide complex using Aspergillus oryzae MTCC 5154. Bioresour Technol. 2009;100:991-5. http://dx.doi.org/10.1016/j.biortech.2008.06.050

11. Brienzo M, Carvalho W, Milagres AMF. Xylooligosaccharides production from alkali-pretreated sugarcane bagasse using xylanases from Thermoascus aurantiacus. Appl Biochem Biotechnol. 2010;162:1195-205. http://dx.doi.org/10.1007/s12010-009-8892-5

12. Gottschalk LMF, Oliveira RA, Bom EPS. Cellulases, xylanases, $\beta$-glucosidase and ferulic acid esterase produced by 
Trichoderma and Aspergillus act synergistically in the hydrolysis of sugarcane bagasse. Biochem Eng J. 2010;51:72-8. http://dx.doi.org/10.1016/j.bej.2010.05.003

13. Yang H, Wang K, Song X, Xu F. Production of xylooligosaccharides by xylanase from Pichia stipitis based on xylan preparation from triploid Populas tomentosa. Bioresour Technol. 2011;102:7171-6. http://dx.doi.org/ 10.1016/j.biortech.2011.03.110

14. Lakshmi GS, Rao CS Rao RS, Hobbs PJ, Prakasham RS. Enhanced production of xylanase by a newly isolated Aspergillus terreus under solid state fermentation using palm industrial waste: A statistical optimization. Biochem Eng J. 2009; 48:51-7. http://dx.doi.org/ 10.1016/j.bej.2009.08.005

15. Moure A, Gullón P, Domínguez H, Parajó JC. Advances in the manufacture, purification and applications of xylooligosaccharides as food additives and nutraceuticals. Process Biochem. 2006;41:1913-23. http://dx.doi.org/10.1016/j.procbio.2006.05.011

16. Polizeli MLTM, Rizzatti ACS, Monti R, Terenzi HF, Jorge JA, Amorim DS. Xylanases from fungi: properties and industrial application. Appl Microbiol Biotechnol. 2005;67:577-91. http://dx.doi.org/10.1007/s00253-005-1904-7

17. Techapun C, Poosaran N, Watanabe M, Sasaki K. Thermostable and alkaline-tolerant microbial cellulase-free xylanases produced from agricultural wastes and the properties required for use in pulp bleaching bioprocess: a review. Process Biochem. 2003;38:1327-40. http://dx.doi.org/10.1016/S0032-9592(02)00331-X

18. Song JM, Wei DZ. Production and characterization of cellulases and xylanases of Cellulosimicrobium cellulans grown in pretreated and extracted bagasse and minimal nutrient medium M9. Biomass Bioenerg. 2010;34:1930-4. http://dx.doi.org/10.1016/j.biombioe.2010.08.010

19. Camassola M, Dillon AJP. Biological pretreatment of sugar cane bagasse for the production of cellulases and xylanases by Penicillium echinulatum. Ind Crop Prod. 2009;29:642-7. http://dx.doi.org/10.1016/j.indcrop.2008.09.008

20. Terrasan CRF, Temer B, Duarte MCT, Carmona EC. Production of xylanolytic enzymes by Penicillium janczewskii. Bioresour Technol. 2010;101:4139-43. http://dx.doi.org/10.1016/j.biortech.2010.01.011

21. Raeder N, Broda P. Rapid preparation of DNA from filamentous fungi. Lett Appl Microbiol. 1985;1:17-20. http://dx.doi.org/10.1111/j.1472-765X.1985.tb01479.x

22. Thompson JD, Higgins DG, Gibson TJ. Clustal W: improving the sensitivity of progressive multiple sequence alignment through sequence weighting positions-specific gap penalties and weight matrix choice. Nucleic Acids Res. 1994;22:4673-80. http://dx.doi.org/10.1093/nar/22.22.4673

23. Tamura K, Dudley J, Nei M, Kumar S. MEGA 4: molecular evolutionary genetics analysis (MEGA) software version 4.0. Mol Biol Evol. 2007;24:1596-9. http://dx.doi.org/10.1093/molbev/msm092

24. Kimura M. A simple model for estimating evolutionary rates of base substitutions through comparative studies of nucleotide sequences. J Mol Evol. 1980;16:111-20. http://dx.doi.org/10.1007/BF01731581

25. Saitou N, Nei M. The neighbor-joining method: a new method for reconstructing phylogenetic trees. Mol Biol Evol. 1987;4:406-25.

26. Miller GL. Use of dinitrosalicylic acid reagent for determination of reducing sugar. Anal Chem. 1959;31:426-8. http://dx.doi.org/10.1021/ac60147a030

27. Iembo T, da Silva R, Pagnocca FC, Gomes E. Production, characterization, and properties of $\beta$-glucosidase and $\beta$-xylosidase from a strain of Aureobasidium sp. Appl Biochem Microbiol. 2002;38:549-52.

http://dx.doi.org/10.1023/A:1020774527212
28. Zilliox C, Debeire P. Hydrolysis of wheat straw by a thermostable endoxylanase: adsorption and kinetic studies. Enzyme Microb Technol. 1998;22:58-63.

http://dx.doi.org/10.1016/S0141-0229(97)00105-1

29. Akpinar O, Erdogan K, Bostanci S. Production of xylooligosaccharides by controlled acid hydrolysis of lignocelulosic materials. Carbohydr Res. 2009;344:660-6. http://dx.doi.org/10.1016/j.carres.2009.01.015

30. Sluiter A, Hames B, Ruiz R, Scarlata C, Sluiter J, Templeton D, Crocker D. Determination of structural carbohydrates and lignin in biomass. Technical report NREL/TP-510-42618, v. 07-08-2011. Golden, CO, USA: National Renewable Energy Laboratory, US Department of Energy; 2011. Available from: www.nrel.gov/biomass/pdfs/42618.pdf.

31. Vázquez MJ, Alonso JL, Domínguez H, Parajó JC. Enzymatic processing of crude xylooligomer solutions obtained by autohydrolysis of eucalyptus wood. Food Biotechnol. 2002;16: 91-105. http://dx.doi.org/10.1081/FBT-120014321

32. Oliveira LA, Porto ALF, Tambourgi EB. Production of xylanase and protease by Penicillium janthinellum CRC 87M-115 from different agricultural wastes. Bioresour Technol. 2006; 97:862-7. http://dx.doi.org/10.1016/j.biortech.2005.04.017

33. Camacho NA, Aguilar G. Production, purification and characterization of a low-molecular-mass xylanase from Aspergillus sp. and its application in baking. App Biochem Biotechnol. 2003;104:159-71.

34. Kolenová K, Vrsanská M, Biely P. Purification and characterization of two minor endo- $\beta-1,4$-xylanases of Schizophyllum commun. Enzyme Microb Technol. 2005;36:903-10. http://dx.doi.org/10.1016/j.enzmictec.2005.01.006

35. Sandrim VC, Rizzatti ACS, Terenzi HF, Jorge JA, Milagres AMF, Polizeli MLTM. Purification and biochemical characterization of two xylanases produced by Aspergillus caespitosus and their potential for kraft pulp bleaching. Process Biochem. 2005;40:1823-28. http://dx.doi.org/10.1016/j.procbio.2004.06.061

36. Chapla D, Pandit P, Shah A. Production of xylooligosaccharides from corncob xylan by fungal xylanase and their utilization by probiotics. Bioresour Technol. 2012;115:215-21. http://dx.doi.org/10.1016/j.biortech.2011.10.083

37. Jayapal N, Samanta AK, Kolte AP, Senani S, Sridhar M, Suresh KP, Sampath KT. Value addition to sugarcane bagasse: xylan extraction and its process optimization for xylooligosaccharides production. Ind Crop Prod. 2013;42:14-24. http://dx.doi.org/10.1016/j.indcrop.2012.05.019

38. Carvalheiro F, Esteves MP, Parajó JC, Pereira H, Girio FM. Production of oligosaccharides by autohydrolysis of brewery's spent grain. Bioresour Technol. 2004;91:93-100. http://dx.doi.org/10.1016/S0960-8524(03)00148-2

39. Chen, MH, Bowman MJ, Dien BS, Rausch KD, Tumbleson ME, Singh V. Autohydrolysis of Miscanthus $\times$ giganteus for the production of xylooligosaccharides (XOS): Kinetics, characterization and recovery. Bioresour Technol. 2014;155:359-65. http://dx.doi.org/10.1016/j.biortech.2013.12.050

40. Otieno DO, Ahring BK. A thermochemical pretreatment process to produce xylooligosaccharides (XOS), arabinooligosaccharides (AOS) and mannooligosaccharides (MOS) from lignocellulosic biomasses. Bioresour Technol. 2012;112:28592. http://dx.doi.org/10.1016/j.biortech.2012.01.162

41. Moura P, Barata R, Carvalheiro F, Gírio F, Loureiro-Dias MC, Esteves MP. In vitro fermentation of xylooligosaccharides from corn cobs autohydrolysis by Bifidobacterium and Lactobacillus strains. LWT - Food Sci Technol. 2007;40:963-72. http://dx.doi.org/10.1016/j.lwt.2006.07.013 